\title{
General meeting of Soviet academy a sensation
}

\section{Moscow}

LAST month's extraordinary meeting of the Soviet Academy of Sciences (18-20 October) was the most dramatic event of its kind I have had to report in 30 years. Despite the news hunger of the Soviet people engendered by glasnost, nobody had expected that the drive for renewal (perestroika) would so quickly touch the bulwark of Soviet science, the academy.

During the meeting, and against a background of complaint about serious problems and shortcomings in Soviet science, the academy voted out half its praesidium, but elected Academician Andrei Sakharov to membership, received 500 million rubles of state funds for priority research programmes, overhauled the system of financing research, decided to set up a foreign trade organization and discussed ways of infusing academic research with youthful talent.

The general meeting had been preceded by an unusual event - a poll among the 400 members and corresponding members of the academy seeking opinions of the state of fundamental science in different fields. Academician Gurii Marchuk, president of the academy, told journalists that the poll had shown that only about 40 per cent of Soviet research projects were considered to exceed or match world standards - fields such as geophysics and ultra-deep drilling, thermonuclear fusion, laser physics and high-temperature superconductivity. Those polled believe the Soviet Union to be behind in information and computer technology and in genetics (condemned as bourgeois science under Stalin)

Marchuk and others noted that theoretical research is of a high standard, but that the shortage of sophisticated instruments had meant that many outstanding theories had not been quickly confirmed; Soviet leadership in some fields had been lost because the needs of fundamental research had too often been overlooked.

On instruments, the academy says that Soviet industry is not interested in manufacturing sophisticated instruments in small numbers, and that its own manufacturing capacity is as yet too small. Imports of equipment are restricted by the shortage of hard currency and by export restrictions by some Western governments, which have a "negative effect on world science, which cannot use to the full extent its intellectual potential for tackling global problems".

The academy's new trading organization has been prompted by the equipment need. Marchuk said that "we must learn to sell ourselves" and to follow Japan in realizing that "the trade in manufactured goods is more profitable than the trade in licences". Some of the output of the new instrument plants will be exported, and there are plans for joint ventures.

To stay ahead in areas where Soviet science leads and to catch up in others, the government has allotted an extra 500 million rubles to certain priority research programmes which, unusually, will be chosen competitively. One of 18 such programmes is that in high-temperature superconductivity, directed by a scientific council headed by Marchuk. But Academician Yuri Osipian, a member of the council, says that although the organizations involved have been given everything they need, they are "looking for some instructions from above".

Competition will also be used to determine the allocation of funds in 100 other areas of lower priority while, from next year, all research programmes at academy institutions will be supported in a new way. Funds will be allocated to projects that experts judge promising. Laboratories not receiving funds may have to work for a related industry.

The academy will also receive funds from government ministries and departments to support research programmes commissioned by the State Committee for Science and Technology. Other funds will flow from contract arrangements with organizations and enterprises.

There is also to be, for the first time, a system of competitive research grants, beginning in information and computer science. Academician Yevgeny Velikhov, a vice-president of the academy, said that there had already been 300 applications, and that awards would be decided by a special commission in November, initially for one year but subsequently for three.

Last month's meeting was also occupied with the problems of age and youth. Many complained that the shortage of youthful talent had become worse in recent years, partly because of the lack of funds for the encouragement of young researchers and partly because of the obstacles to the dismissal of incompetent and lazy workers. The lack of housing was recognized to restrict the mobility of scientists.

But most excitement at the meeting was engendered by the elections. Although the practice of electing directors of institutes and heads of departments and laboratories is gaining ground the electoral procedure is far from perfect, and has yet to be thought out. A secret ballot of all the workers in an institution may produce the most acceptable administrative manager rather than the best organizer of research.

The general meeting of the academy, however, rejected the proposal (already imposed on political leaders and industrial managers) that the terms of office of institute directors and other research leaders should be limited to ten years. One speaker argued that the rule would have banished Pyotr Kapitza, who founded the Moscow Institute of Physical Problems after his return from Cambridge in 1934

The academy's own elections, brought forward from 1990 by the new rules requiring members of the praesidium to be 70 or younger, caused a sensation in academic circles - indeed, in the Soviet Union as a whole. Five new vice-presidents were elected without difficulty (see Nature 335, 753; 1988) as were eight new departmental secretaries nominated by their departments. But there was heated debate about the election of the remaining members of the praesidium.

The election of Andrei Sakharov, in itself remarkable, also caused a stir because he had been nominated by Academician Roald Sagdeev, former director of the Institute of Space Research, who had resigned his post six weeks earlier (see Nature 334, 189; 1988). Sagdeev had also been nominated, but stood down in favour of Sakharov, saying that the praesidium should include "people with a broad vision and developed sense of moral and social responsibility to the nation and the world". Marchuk said that Sakharov's election was "further proof of the success of the drive for democratization".

Among other comments on the praesidium elections, physicist Andrei GaponovGrekhov (also excluded because only one physicist was eligible) ranked the three candidates in the order "Sakharov, Sagdeev and Gaponov-Grekhov", while mathematician Israil Gelfand said "For the first time, we have had to choose between the good and the best" and went on to plead that all three should be elected. But a formal proposal by Academician Vitaly Ginsburg that members of the praesidium should be elected as scientists, without regard to discipline, was voted down.

The question remains of why the praesidium should be restricted to 47 members, also the reason why sociologist Academician Tatyana Zaslavskaya was not elected last month. In an emotional speech in her support, Academician Natalya Cekhtereva, director of the Institute of Experimental Medicine, said "we have only one woman in the praesidium, and she is in the picture", which was a reference to the portrait of Countess Yekaterina Dashkova, president of the academy in the late eighteenth century.

On another historical theme, the general meeting voted unanimously for the posthumous reinstatement as a full member of Nikolai Bukharin, a close colleague of Lenin who was brought to trial during the Stalin terror, executed and stripped of his academic title at a general meeting of the academy in 1937 .

Yuri Kanin Novosti 